\title{
PENGARUH BRAND IMAGE DAN ATRIBUT PRODUK TERHADAP MINAT BELI HANDPHONE MEREK OPPO
}

\author{
Hermansyah \\ Fakultas Ilmu Sosial dan Ilmu Politik Universitas Kapuas Sintang \\ Email: hermansyah.unkas90@gmail.com
}

\begin{abstract}
ABSTRAK: Penelitian ini bertujuan untuk mengetahui dan menganalisis Pengaruh Brand Image Dan Atribut Produk Terhadap Minat Beli Handphone Merek Oppo. Responden dalam penelitian ini adalah konsumen yang membeli merek Oppo setiap bulannya sebanyak 55 Orang Konsumen. Teknik pengambilan sampel dalam penelitian ini adalah total sampling. Hasil penelitian menunjukan secara parsial maupun secara Simultan Variabel Brand Image $\left(\mathrm{X}_{1}\right)$ dan Variabel Atribut Produk $\left(\mathrm{X}_{2}\right)$ berpengaruh positif dan signifikan terhadap Variabel Minat Beli (Y) Handphone Merek Oppo.
\end{abstract}

\section{Kata Kunci: Brand Image, Atribut Produk, Minat Beli}

\section{PENDAHULUAN}

Kemajuan teknologi menyebabkan perubahan yang begitu besar pada kehidupan umat manusia. Perubahan akan memberikan dampak yang begitu besar terhadap transformasi nilai-nilai dan gaya hidup yang ada di masyarakat. Saat ini, dapat dirasakan begitu besar pengaruh kemajuan teknologi terhadap nilai-nilai kebudayaan di masyarakat. Kemajuan teknologi telah menciptakan permerintaan terhadap fasilitas komunikasi.

Kebutuhan akan komunikasi adalah hal yang sangat penting bagi setiap setiap individu. Kebutuhan tersebut berdampak pada meningkatnya permintaan akan berbagai jenis alat komunikasi yang mengakibatkan semakin banyaknya persaingan dalam dunia bisnis di bidang telekomunikasi. Hal tersebut dapat dilihat dari banyaknya produsen produk-produk alat komunikasi seperti Handphone yang menawarkan berbagai jenis produk baru dengan inovasi yang berbeda dari produk-produk sebelumnya, dimana produk yang di hasilkan banyak memberikan kemudahan bagi para konsumen dalam melakukan komunikasi. Dunia bisnis produk komunikasi berlomba-lomba supaya dapat menarik minat beli para calon konsumen dan memutuskan membeli serta menggunakan produknya.

Kebutuhan akan alat komunikasi seperti telepon seluler Handphone atau smartphone sendiri selalu mengalami peningkatan dari tahun ketahun terutama untuk jenis-jenis Handphone atau smartphone dengan merek-merek tertentu. Hal ini dikarenakan pola konsumsi konsumen pada saat ini yang selalu menginginkan sebuah kemudahan dalam komunikasi yang dapat mendukung aktivitas sehari-hari baik dalam bekerja maupun hal yang lainnya. Oleh karena itu banyak perusahaan di bidang komunikasi menciptakan berbagai merek Handphone dengan berbagai varian merek, harga dan fitur produk dari spesifikasi yang terendah sampai pada sepesifikasi yang tertinggi. Hal ini dilakukan untuk memenuhi ekspektasi dari konsumen.

Kondisi ini berkembang menjadi semakin kompetitif, semakin kompleks, bergerak dengan pesat serta semakin sulit untuk diprediksi. Banyak kebutuhan masyarakat atas barang dan jasa juga menjadi beragam semakin baik jenis, macam dan kualitasnya. Semakin tinggi tingkat persaingan, mengakibatkan setiap perusahaan saling berebut untuk mendapatkan dan mempertahankan konsumen.

Strategi untuk memenuhi keinginan dan kebutuhan konsumen diantaranya adalah dengan merespon kebutuhan dan keinginan. pengambilan keputusan suatu proses penilaian dan pemilihan dari berbagai alternatif sesuai sesuai dengan kepentingan-kepentingan tertentu dengan menetapkan suatu kepentingankepentingan tertentu dengan menetapkan suatu pilihan yang dianggap paling menguntungkan. Dari berbagai faktor yang mempengaruhi konsumen dalam melakukan pembelian suatu produk atau jasa, dengan mempertimbangkan Brand Image dan atribut produk yang sudah dikenal masyarakat. 
Brand atau merek menjadi hal dominan pada era globalisasi saat ini. Brand adalah salah satu faktor penting dalam kompetisi dan merupakan aset perusahaan yang bernilai. Merek atau Brand adalah bagian dari consideration set yang mempengaruhi preferensi pelanggan dalam memilih merek dan melakukan keputusan pembelian. Brand juga sangat berpengaruh dalam menciptakan keunggulan bersaing melalui kapabilitasnya dibenak konsumen. Brand digunakan untuk memberikan diferensiasi produk dari pesaingnya. Dari Brand inilah tercipta symbol atau atribut yang merupakan identitas dari merek itu sendiri dan bagi konsumennya.

Atribut produk adalah suatu komponen yang merupakan sifat-sifat produk yang menjamin agar produk tersebut dapat memenuhi kebutuhan dan ke inginan yang diharapkan oleh pembeli. Hal ini juga dapat mempengaruhi keputusan konsumen dalam melakukan pembelian produk.

CV. Indah Mesindo Di Kabupaten Sintang merupakan salah satu perusahaan comanditer yang bergerak dalam bidang pemasaran Handphone. Berdasarkan hasil pra-penelitian yang dilakukan diketuhui bahwa CV. Indah Mesindo Di Kabupaten Sintang menjual berbagai merek Handphone dan type-nya seperti Oppo, Vivo, Samsung dan Xiaomi.

Sementara data penjualan secara rata-rata untuk masing-masing merek setiap bulannya pada tahun 2018 seperti terlihat pada tabel berikut ini.

Tabel 1. Rata-rata Jumlah Konsumen Handphone Setiap Bulan Pada CV. Indah Mesindo Tahun 2018

\begin{tabular}{|c|c|c|c|c|c|}
\hline No & Merek & Type & $\begin{array}{c}\text { Jumlah Konsumen } \\
\text { (Orang) }\end{array}$ & Persetase & $\begin{array}{l}\text { Kontribusi } \\
\text { Penjualan }\end{array}$ \\
\hline \multirow[t]{3}{*}{1} & Oppo & A3s & 30 & $22,73 \%$ & \\
\hline & & F7 & 15 & $11,36 \%$ & \\
\hline & & F9 & 10 & $7,58 \%$ & $41,67 \%$ \\
\hline \multirow[t]{4}{*}{2} & Vivo & Y71 & 15 & $11,36 \%$ & \\
\hline & & Y83 & 10 & $7,58 \%$ & \\
\hline & & V9 & 5 & $3,79 \%$ & \\
\hline & & V11 & 3 & $2,27 \%$ & $25,00 \%$ \\
\hline \multirow[t]{7}{*}{3} & Samsung & $\mathrm{J} 2$ prime & 5 & $3,79 \%$ & \\
\hline & & $\mathrm{J} 2$ pro & 5 & $3,79 \%$ & \\
\hline & & $\mathrm{J} 4$ & 5 & $3,79 \%$ & \\
\hline & & J6 & 3 & $2,27 \%$ & \\
\hline & & $\mathrm{J} 8$ & 2 & $1,51 \%$ & \\
\hline & & $\mathrm{Tab} 3 \mathrm{v}$ & 2 & $1,51 \%$ & \\
\hline & & Tab a6 & 2 & $1,51 \%$ & $18,17 \%$ \\
\hline \multirow[t]{5}{*}{4} & Xiaomi & Redmi 6a & 5 & $3,79 \%$ & \\
\hline & & Redmi 5 & 5 & $3,79 \%$ & \\
\hline & & Redmi 5 plus & 5 & $3,79 \%$ & \\
\hline & & Note 5 & 5 & $3,79 \%$ & $15,16 \%$ \\
\hline & & & 132 & $100,00 \%$ & $100,00 \%$ \\
\hline
\end{tabular}

Sumber: CV. Indah Mesindo Sintang tahun 2019

Tabel 1 di atas terlihat bahwa Handphone merek Oppo memberikan kontribusi sebesar 41,67\%, merek Vivo 25,00\% , Merek Samsung $18,17 \%$ dan merek Xiaomi sebesar $15,16 \%$. Dengan demikian diketahui bahwa konsumen lebih banyak memilih Handphone merek Oppo dibandingkan dengan merek lain seperti merek
Vivo, Samsung dan merek Xiaomi. Handphone merek Oppo yang banyak dibeli oleh konsumen adalah merek Oppo dengan type A3s. Handphone Oppo type A3s memiliki harga yang murah dikelasnya dan tidak jauh berbeda dengan harga Handphone merek Vivo, Samsung dan merek Xiaomi. 
Berdasar uaraian di atas penulis menyakini bahawa keputusan konsumen menentukan pilihan untuk melakukan pembelian produk Handphone merek tertentu seperti Merek Oppo dipengaruhi oleh tingkat Brand Image, dan atribut produk dari Handphone itu sendiri. Beranjak dari problema tersebut di atas, maka penulis merasa tertarik untuk melakukan penelitian dengan judul: Pengaruh Brand Image Dan Atribut Produk Terhadap Minat beli Handphone merek Oppo. Adapun tujuan dari penelitian ini adalah untuk mengetahui dan menganalisis pengaruh Brand Image, dan atribut produk secara simultan terhadap minat beli Handphone Merek Oppo.

\section{LANDASAN TEORI}

Pemasaran dapat didefinisikan sebagai kegiatan yang bersangkutan dengan berpindahnya barang dari produsen pertama ke konsumen terakhir, sedangkan Kotler (2000) mendefinisikan pemasaran sebagai suatu proses sosial dan manajerial di mana individu dan kelompok mendapatkan kebutuhan dan keinginan mereka dengan menciptakan, menawarkan, dan bertukar sesuatu yang bernilai satu sama lain.

Sementara Swastha (2000) menyatakan bahwa: Pemasaran merupakan suatu usaha untuk memuaskan kebutuhan pembeli dan penjual. Dari beberapa definisi para ahli tentang pemasaran di atas, maka dapat disimpulkan bahwa yang dimaksud dengan pemasaran adalah rangkaian kegiatan yang berhubungan dengan perpindahan produk baik berupa barang dan jasa yang dapat memuaskan kebutuhan konsumen.

\section{Brand Image}

Brand sebagai salah satu atribut yang penting dari sebuah produk yang penggunaannya pada saat ini sudah sangat meluas. Keahlian paling unik dari pemasar adalah kemampuannya menciptakan, memelihara, melindungi dan meningkatkan Brand. Pemberian Brand adalah seni dan bagian penting dalam pemasaran. Brand juga dapat membantu perusahaan memperluas lini produk serta mengembangkan posisi pasar yang spesifik bagi suatu produk.

Menurut Simamora (2001) Brand adalah nama, tanda, istilah, simbol, desain, atau kombinasinya yang ditujukan untuk mengidentifikasi dan mendiferensiasi (membedakan) barang atau layanan suatu penjual dari barang atau layanan penjual lain. Sedangkan pengertian Brand menurut Kotler dan Amstrong
(2012) Brand adalah suatu nama, kata, tanda, symbol, atau desain atau kombinasi dari semuanya yang mengidentifikasikan pembuat atau penjual produk dan jasa tertentu. Dari pengertian-pengertian di atas simbol, tanda mengidentifikasi produk dan membedakan perusahaan dengan produk lainnya. Menurut Kotler (2000) Pengertian Image adalah persepsi masyarakat terhadap perusahaan atau produknya. Pengertian Image secara umum, merupakan sekumpulan keyakinan, ide, kesan, dan persepsi dari seseorang, suatu komunitas, atau masyarakat terhadap suatu produk, merek, indikator, organisasi, perusahaan bahkan Negara yang dibentuk melalui suatu proses informasi yang diperoleh melalui berbagai sumber.

Menurut Kotler (2000) Image yang positif mempunyai 3 fungsi, yaitu: (1). Membentuk karakter produk atau perusahaan; (2). Image membentuk karakter tersebut dengan cara tersendiri, sehingga tidak keliru dengan pesaing; (3). Image menyalurkan kekuatan emosional.

Menurut Kotler (2008) Brand Image (citra merek) adalah persepsi dan keyakinan yang dilakukan oleh konsumen, seperti tercermin dalam asosiasi yang terjadi dalam memori konsumen. Lebih lanjut Kotler (2008:215) mangatakan Brand Image (citra merek) sebagai seperangkat keyakinan, ide, dan kesan yang dimiliki oleh seseorang terhadap suatu merek. Karena itu sikap dan tindakan konsumen terhadap suatu merek sangat ditentukan oleh citra merek tersebut.

Selanjutnya Kotler dan Armstrong (2012) menyatakan Brand Image adalah himpunan keyakinan konsumen mengenai berbagai merek . Intinya Brand Image menggambarkan tentang asosiasi dan keyakinan konsumen terhadap merek tertentu. Dari sebuah produk dapat lahir sebuah brand jika produk itu menurut persepsi konsumen mempunyai keunggulan fungsi, menimbulkan asosiasi dan citra yang diinginkan konsumen dan membangkitkan pengalaman tertentu.

Indikator yang digunakan untuk mengukur Brand Image menurut Aaker dialihbahasakan oleh Ananda (2011) adalah sebagai berikut : (1). Recognition; (pengakuan); (2). Reputation (reputasi); (3). Affinity (afinitas); (4) . Domain

\section{Atribut Produk}

Kotler (2008) menyatakan bahwa atribut produk adalah suatu komponen yang merupakan sifat-sifat produk yang menjamin agar produk 
tersebut dapat memenuhi kebutuhan dan keinginan yang diterapkan oleh pembeli. Definisi produk menurut Stanton (2012) sekumpulan atribut yang nyata dan tidak nyata didalamnya sudah tercakup warna, kemasan, prestise pengecer dan pelayanan dari pabrik, serta pengecer yang mungkin diterima oleh pembeli sebagai suatu yang bisa memuaskan keinginannya.

Menurut Tjiptono (2008) Atribut produk adalah unsur-unsur produk yang dipandang penting oleh konsumen dan dijadikan dasar pengambilan keputusan pembelian. Dengan adanya atribut yang melekat pada suatu produk yang digunakan konsumen untuk menilai dan mengukur kesesuaian karakteristik produk dengan kebutuhan dan keinginan. Bagi perusahaan dengan mengetahui atribut-atribut apa saja yang bisa mempengaruhi keputusan pembelian maka dapat ditentukan strategi untuk mengembangkan dan menyempurnakan produk agar lebih memuaskan konsumen.

\section{Minat Beli}

Perilaku konsumen (consumer behavior) dapat didefinisikan sebagai kegiatan-kegiatan individu yang secara langsung terlibat dalam mendapatkan dan mempergunakan barang dan jasa, termasuk di dalamnya proses pengambilan keputusan pada persiapan dan penentuan kegiatan-kegiatan tersebut. Menurut Anaroga (2000) Perilaku konsumen merupakan perilaku konsumen yang ditunjukkan melalui pencarian, pembelian, penggunaan, pengevaluasian, dan penentuan produk atau jasa yang diharapkan dapat memuaskan kebutuhan konsumen Sementara Sumarwan (2003) menyatakan Perilaku konsumen adalah semua kegiatan, tindakan, serta proses psikologis yang mendorong tindakan tersebut pada saat sebelum membeli, ketika membeli, menggunakan, menghabiskan produk dan jasa setelah melakukan hal-hal di atas atau kegiatan mengavaluasi.

Perilaku konsumen dapat diartikan sebagai atau kegiatan-kegiatan individu, yang secara langsung terlibat dalam mendapatkan serta menggunakan barang-barang dan jasa-jasa termaasuk di dalamnya proses pengambilan keputusan pada persiapan dan penentuan kegiatan tersebut. Pengertian tersebut mengandung unsur yaitu proses pengambilan keputusan sebagai kegiatan yang tidak nampak pada dasarnya termasuk dalam perilaku, karena kegiatan yang tampak adalah atau hasil dari pengambilan keputusan.jadi perilaku konsumen meliputi apa yang dibeli, akan tetapi juga di mana, berapa banyak atau sering dan dalam kondisi bagaimana konsumen membeli suatu barang.

Berdasarkan uaraian di atas dapat dikatakan bahwa untuk mengukur minat belikonsumen dapat dilihat dari beberapa aspek seperti: kecenderungan seseorang untuk membeli produk; kecenderungan seseorang untuk mereferensikan produk kepada orang lain; seseorang yang memiliki preferensi utama pada produk tersebut; dan seseorang yang selalu mencari informasi mengenai produk yang diminatinya.

\section{METODE PENELITIAN}

Rancangan penelitian harus memuat segala sesuatu yang berkepentingan dengan pelaksanaan penelitian yang akan dilaksanakan. Menurut Bungin (2008) Rancangan penelitian adalah pedoman ataupun acuan penelitian yang akan dilaksanakan oleh peneliti. Secara lebih spesifik, penelitian ini merupakan penelitian korelasional, karena penelitian ini bertujuan mencari ada tidaknya hubungan antara satu variabel dengan variabel lainnya.

Menurut Arikunto (2013) penelitian korelasional adalah penelitian yang dilakukan oleh peneliti untuk mengetahui tingkat hubungan antara dua variabel atau lebih, tanpa melakukan perubahan, tambahan atau manipulasi terhadap data yang memang sudah ada. Dimana variabel bebas yang terdiri dari: Brand Image dan Atribut Produk serta variabel terikat adalah Minat Beli.

Populasi dalam penelitian ini adalah ratarata jumlah konsumen yang membeli merek Oppo setiap bulannya sebanyak 55 Orang Konsumen. Teknik pengambilan sampel dalam penelitian ini adalah total sampling. Menurut Sugiyono (2007) Total sampling adalah teknik pengambilan sampel dimana jumlah sampel sama dengan populasi. Alasan mengambil total sampling karena menurut jumlah populasi yang kurang dari 100 seluruh populasi dijadikan sampel penelitian semuanya. Sampel yang diambil dari penelitian ini adalah 55 orang.

\section{HASIL PENELITIAN DAN PEMBAHASAN UJi Validitas Dan Reliabilitas 1. Uji Validitas}

Berikut ini adalah tabel hasil pengolahan data untuk uji valididitas Brand Image $\left(\mathrm{X}_{1}\right)$ dan Atribut Produk $\left(\mathrm{X}_{1}\right)$ serta Minat beli (Y) dengan menggunakan program SPSS terhadap 55 orang responden. 
108. Fokus, Volume 19, Nomor 1, Maret 2021, hlm. 104 - 111

Tabel 2. Uji Validitas Brand Image $\left(\mathrm{X}_{1}\right)$ dan Atribut Produk $\left(\mathrm{X}_{2}\right)$ serta Minat beli (Y)

\begin{tabular}{|c|c|c|c|c|}
\hline \multicolumn{5}{|c|}{ Variabel Brand Image (X1) } \\
\hline No & Pertanyaan & $\begin{array}{c}\text { Pearson } \\
\text { Correlation }\end{array}$ & $\begin{array}{l}\text { Sig. }(2- \\
\text { tailed })\end{array}$ & Keterangan \\
\hline $\mathrm{X} 1.1$ & Merek sangat terkenal & $.823^{* *}$ & ,000 & Valid \\
\hline $\mathrm{X} 1.2$ & Memiliki track record yang baik & $.778^{* *}$ &, 000 & Valid \\
\hline & Disukai konsumen dan memiliki reputasi & & & \\
\hline $\mathrm{X} 1.3$ & yang baik & $.862^{* *}$ & 000 & Valid \\
\hline $\mathrm{X} 1.4$ & Bentuk dan ukuran yang paling ideal & $.817^{* *}$ & ,000 & Valid \\
\hline \multicolumn{5}{|c|}{ Variabel Atribut Produk (X2) } \\
\hline No & Pertanyaan & $\begin{array}{c}\text { Pearson } \\
\text { Correlation }\end{array}$ & $\begin{array}{l}\text { Sig. }(2- \\
\text { tailed })\end{array}$ & Keterangan \\
\hline $\mathrm{X} 2.1$ & Designya dan warna yang menarik & $.888^{* *}$ & ,000 & Valid \\
\hline $\mathrm{X} 2.2$ & Kemasan yang menarik & $.762^{* *}$ & ,000 & Valid \\
\hline & Informasi mengenai produk yang jelas & & & \\
\hline $\mathrm{X} 2.3$ & dan mudah di pahami & $.873^{* *}$ & ,000 & Valid \\
\hline $\mathrm{X} 2.4$ & Layanan servis yang mudah & $.889^{* *}$ & ,000 & Valid \\
\hline $\mathrm{X} 2.5$ & Garansi kepada konsumenya & $.744^{* *}$ & 000 & Valid \\
\hline \multicolumn{5}{|c|}{ Variabel Minat Beli (Y) } \\
\hline No & Pertanyaan & $\begin{array}{c}\text { Pearson } \\
\text { Correlation }\end{array}$ & $\begin{array}{l}\text { Sig. }(2- \\
\text { tailed) }\end{array}$ & Keterangan \\
\hline Y1 & $\begin{array}{l}\text { Lebih memilih untuk membeli } \\
\text { Handphone Merek Oppo } \\
\text { Lebih mereferensikan Handphone }\end{array}$ & $.824^{* *}$ & 000 & Valid \\
\hline $\mathrm{Y} 2$ & $\begin{array}{l}\text { Merek Oppo kepada orang lain } \\
\text { Handphone Merek Oppo preferensi }\end{array}$ & $.774^{* *}$ &, 000 & Valid \\
\hline Y3 & utama & $.867^{* *}$ & ,000 & Valid \\
\hline Y4 & $\begin{array}{l}\text { Mencari informasi mengenai Handphone } \\
\text { Merek Oppo }\end{array}$ & $.821^{* *}$ & ,000 & Valid \\
\hline
\end{tabular}

Sumber: Data Primer, diolah 2019

Pada tabel 2 merupakan hasil pengolahan data menunjukan seluruh pertanyaan yang terdapat pada variabel Brand Image $\left(\mathrm{X}_{1}\right)$ dan Atribut Produk $\left(\mathrm{X}_{2}\right)$ serta Minat beli $(\mathrm{Y})$ dengan hasil korelasi (Sig. (2-tailed) lebih kecil dari 0,05. Dengan demikian seluruh pertanyaan yang berhubungan dengan Brand Image $\left(\mathrm{X}_{1}\right)$ dan Atribut Produk $\left(\mathrm{X}_{2}\right)$ serta Minat beli $(\mathrm{Y})$ layak digunakan sebagai instrumen dalam penelitian ini.

\section{Uji Reliablitas}

Reliabilitas digunakan untuk valid atau tidaknya alat ukur yang digunakan oleh peneliti. Uji reliabilitas dilakuan terhadap Variabel Brand Image $\left(\mathrm{X}_{1}\right)$ dan Variabel Atribut Produk $\left(\mathrm{X}_{2}\right)$ serta Variabel Minat beli(Y). 
Hermansyah, Pengaruh Brand Image dan Atirubut Produk Terhadap Minat Beli Handphone Merek Oppo 109

Tabel 3 Uji Reliabilitas Variabel Brand Image $\left(\mathrm{X}_{1}\right)$ dan Variabel Atribut Produk $\left(\mathrm{X}_{2}\right)$ serta Variabel Minat beli (Y)

\begin{tabular}{|c|l|c|c|c|}
\hline No & \multicolumn{1}{|c|}{ Variabel } & $\begin{array}{c}\text { Cronbach's } \\
\text { Alpha }\end{array}$ & $\begin{array}{c}\text { Cronbach's Alpha } \\
\text { Standar }\end{array}$ & Keterangan \\
\hline 1 & Brand Image (X1) & 0,835 & 0,6 & Reliabel \\
2 & Atribut Produk (X2) & 0,889 & 0,6 & Reliabel \\
3 & Minat Beli (Y) & 0,836 & 0,6 & Reliabel \\
\hline
\end{tabular}

Sumber: Data Primer, diolah 2019

Berdasarkan hasil pengolahan data seperti yang terdapat pada Tabel 3, maka instrumen pertanyaan dapat dikatakan reliable karena memiliki koefisien reliabilitas lebih besar dari 0,6. Dimana Cronbach's Alpha lebih besar dari Cronbach'sAlpha Standar dengan demikian semua pertanyaan dapat dikatakan reliable dalam penelitian ini.

\section{Analisis Regresi Linier Berganda}

Analisis Regresi Linier Berganda dilakukan untuk menganalisis hubungan antara variabel terikat dengan variabel bebas. Pada penelitian ini, peneliti akan mengubungkan antara Variabel Brand Image dan Atribut Produk dengan Minat Beli Handphone Merek Oppo dengan menggunakan adalah Variabel Variabel Brand Image $\left(\mathrm{X}_{1}\right)$ dan Variabel Atribut Produk $\left(\mathrm{X}_{2}\right)$ serta Variabel Minat beli (Y) sebagai variabel terikat.

Tabel 4 Koefisien Regresi Variabel Brand Image $\left(\mathrm{X}_{1}\right)$, Variabel Atribut Produk $\left(\mathrm{X}_{2}\right)$ dan Variabel Minat beli (Y)

\begin{tabular}{|c|c|c|c|c|c|c|}
\hline \multicolumn{7}{|c|}{ Coefficients $^{\mathrm{a}}$} \\
\hline & & $\begin{array}{r}\text { Unsta } \\
\text { Coe }\end{array}$ & $\begin{array}{l}\text { dardized } \\
\text { ficients }\end{array}$ & $\begin{array}{l}\text { Standardized } \\
\text { Coefficients }\end{array}$ & & \\
\hline \multicolumn{2}{|c|}{ Model } & B & Std. Error & Beta & $\mathrm{T}$ & Sig. \\
\hline \multirow[t]{3}{*}{1} & (Constant) & -.180 & .286 & & -.629 & .532 \\
\hline & Brand Image (X1) & .768 & .068 & .710 & 11.271 & .000 \\
\hline & Atribut Produk (X2) & .231 & .050 & .290 & 4.606 & .000 \\
\hline
\end{tabular}

a. Dependent Variable: Minat Beli (Y)

Sumber: Data Primer, diolah 2019

Berdasarkan hasil pengolahan data dengan menggunakan Program SPSS diperoleh hasil sebagai berikut:

1. Regresi Linear Berganda $\mathrm{Y}=-0,180+$ $0,768 \mathrm{X}_{1}+0,231 \mathrm{X}_{2}$

2. Nilai $\mathrm{a} 0=-0,180$ memiliki makna nilai konstanta ini menunjukkan bahwa apabila tidak ada variabel Brand Image $\left(\mathrm{X}_{1}\right)$ dan Variabel Atribut Produk $\left(\mathrm{X}_{2}\right)$, maka akan berpengaruh negatif terhadap variabel Minat beli (Y) Handphone Merek Oppo.

3. Nilai a1 $=0,768$ merupakan nilai koefisien regresi variabel Brand Image $\left(\mathrm{X}_{1}\right)$ maka secara parsial variabel faktor Brand Image $\left(\mathrm{X}_{1}\right)$ berpengaruh positif terhadap variabel Minat beli Handphone Merek Oppo dengan asumsi bahwa Variabel Atribut Produk $\left(\mathrm{X}_{2}\right)$ dianggap tetap atau konstan.
4. Nilai a2 $=0,231$ merupakan nilai koefisien regresi Variabel Atribut Produk $\left(\mathrm{X}_{2}\right)$ maka secara parsial variabel faktor Atribut Produk $\left(\mathrm{X}_{2}\right)$ berpengaruh positif terhadap variabel Minat beli (Y) Handphone Merek Oppo dengan asumsi bahwa variabel Brand Image $\left(\mathrm{X}_{1}\right)$ dianggap tetap atau konstan.

\section{Uji $t$ (Pengujian secara Parsial)}

Uji t berarti melakukan pengujian terhadap koefisien regresi secara parsial. Pengujian ini dilakukan untuk mengetahui signifikansi peran secara parsial antara dependent terhadap independ dependen dengan mengasumsikan bahwa independent lain dianggap konstan. Hasil pengolahan data seperti yang terdapat pada Tabel 4 di atas menunjukan hasil sebagai berikut: 
1. Nilait ${ }_{\text {hitung }}$ Variabel Brand Image $\left(\mathrm{X}_{1}\right)=11,271$ dan Nilai Sig $(0,00)<$ á $(0,05)$ berarti terdapat pengaruh Brand Image secara parsial terhadap minat beli Handphone merek Oppo. Variabel Brand Image $\left(\mathrm{X}_{1}\right)$ dengan nilai $\mathrm{t}_{\text {hitung }} 11,271$ dan probabilitas Sig $(0,00)<$ á $(0,05)$ memeberikan pengaruh positif terhadap minat beli Handphone Merek Oppo. Artinya semakin baik atau meningkatnya variabel Brand Image $\left(\mathrm{X}_{1}\right)$ barupa merek sangat terkenal, memiliki track record yang baik, disukai konsumen dan memiliki reputasi yang baik, bentuk dan ukuran yang paling ideal akan menyebabkan meningkatnya minat beli Handphone merek Oppo.

2. Nilai $t_{\text {hitung }}$ Variabel Atribut Produk $\left(X_{2}\right)=4.606$ dan Nilai Sig $(0,00)<$ á $(0,05)$. berarti terdapat pengaruh atribut produk secara parsial terhadap minat beli Handphone merek Oppo. Variabel Atribut Produk $\left(\mathrm{X}_{2}\right)$ dengan nilai $\mathrm{t}$
= 4.606 dan Nilai Sig $(0,00)<$ á $(0,05)$ memeberikan pengaruh positif terhadap minat beli handphone merek Oppo. Artinya semakin baik atau meningkatnya Variabel Atribut Produk $\left(\mathrm{X}_{2}\right)$ barupa designya dan warna yang menarik, kemasan yang menarik, informasi mengenai produk yang jelas dan mudah di pahami, layanan servis yang mudah dan garansi kepada konsumenya akan menyebabkan meningkatnya minat beli Handphone merek Oppo.

\section{Uji Pengaruh simultan ( $F$ test $)$}

Uji secara Simultan atau serentak maka digunakan uji $\mathrm{F}$ (ANOVA) dengan memasukan seluruh Variabel bebas yang terdiri dari Variabel Brand Image $\left(\mathrm{X}_{1}\right)$ dan Variabel Atribut Produk $\left(\mathrm{X}_{2}\right)$ dan Variabel Minat Beli (Y) adalah sebagai berikut:

Tabel 5 Hasil Uji F (Analisys Of Varian = ANOVA)

\begin{tabular}{|c|c|c|c|c|c|c|}
\hline \multicolumn{7}{|c|}{ ANOVA $^{b}$} \\
\hline \multicolumn{2}{|c|}{ Model } & Sum of Squares & df & Mean Square & $\mathrm{F}$ & Sig. \\
\hline 1 & Regression & 198.143 & 2 & 99.072 & 1608.881 & $.000^{\mathrm{a}}$ \\
\hline & Residual & 3.202 & 52 & .062 & & \\
\hline & Total & 201.345 & 54 & & & \\
\hline
\end{tabular}

a. Predictors: (Constant), Atribut Produk (X2), Brand Image (X1)

b. Dependent Variable: Minat Beli (Y)

Sumber: Data Primer, diolah 2019

Nilai F hitung $=1.608,881$ dan Nilai $\operatorname{Sig}=$ 0,000. sementara ketentuan keputusan tentang penerimaan dan penolakan hipotesis jika Nilai Sig $(0,000)<$ á $(0,05)$ berarti secara simultan Variabel Brand Image $\left(\mathrm{X}_{1}\right)$ dan Variabel Atribut Produk $\left(\mathrm{X}_{2}\right)$ terhadap Variabel Minat Beli (Y) Handphone merek Oppo.

\section{Koefisien Determinasi}

Analisis koefesien determinasi $\left(\mathrm{R}^{2}\right)$ digunakan untuk mengetahui berapa besar kemampuan Variabel Brand Image $\left(\mathrm{X}_{1}\right)$ dan Variabel Atribut Produk $\left(\mathrm{X}_{2}\right)$ dalam menerangkan atau menjelaskan terhadap variasi naik turunnya Variabel Terikat Minat beli (Y) Handphone merek Oppo adalah sebagai berikut:

Tabel 6 Koefisien Korelasi dan Koefisien Determinasi

\begin{tabular}{|c|c|c|c|c}
\hline \multicolumn{5}{c}{ Model Summary } \\
\hline Model & $\mathrm{R}$ & R Square & Adjusted R Square & $\begin{array}{c}\text { Std. Error of the } \\
\text { Estimate }\end{array}$ \\
\hline 1 & $.992^{\mathrm{a}}$ & .984 & .983 & .24815 \\
\hline \multicolumn{2}{|l}{ a. Predictors: (Constant), Atribut Produk (X2), Brand Image (X1) } \\
\hline
\end{tabular}

Sumber: Data Primer, diolah 2019 
Koefisien korelasi ganda $\mathrm{r}$ (Multiple R) sebesar 0,992 atau mendekati nilai 1, yang berarti antara faktor Variabel Brand Image $\left(\mathrm{X}_{1}\right)$ dan Variabel Atribut Produk $\left(\mathrm{X}_{2}\right)$ dengan Variabel Minat Beli (Y) Handphone merek Oppo menunjukkan hubungan yang kuat dan searah (positif). Jadi korelasi antara Variabel Brand Image $\left(\mathrm{X}_{1}\right)$ dan Variabel Atribut Produk $\left(\mathrm{X}_{2}\right)$ tersebut di atas dengan Variabel Minat Beli (Y) sangat kuat dan positif.

Koefisien determinasi ( $\mathrm{R}$ square atau $\mathrm{R}^{2}$ ), yaitu untuk mengetahui besarnya pengaruh variabel independent $(\mathrm{X})$ terhadap variabel dependen $(\mathrm{Y})$. Dari tabel diatas diperoleh hasil nilai $\mathrm{R}$ Square sebesar 0,984 berarti bahwa $(0,984 \times 100 \%)=$ 98,4\% Variabel Minat Beli (Y) Handphone merek Oppo akan pengaruhi oleh Variabel Brand Image $\left(X_{1}\right)$ dan Variabel Atribut Produk $\left(X_{2}\right)$ sedangkan sisanya sebesar $1,6 \%$ akan dipengaruhi oleh faktor lain di luar persamaan model regresi.

\section{PENUTUP}

Berdasarkan hasil penelitian bahwa hubungan Variabel Brand Image $\left(\mathrm{X}_{1}\right)$ dan Variabel Atribut Produk $\left(\mathrm{X}_{2}\right)$ dengan Variabel Minat Beli (Y) digambarkan pelalui Persamaan Regresi Linear Berganda $Y=-0,180+0,768 X_{1}+0,231 X_{2}$. Variabel Brand Image $\left(\mathrm{X}_{1}\right)$ dan Variabel Atribut Produk $\left(\mathrm{X}_{2}\right)$ memiliki hubungan yang sangat kuat/ erat dengan Variabel Minat Beli (Y). Secara parsial maupun secara Simultan Variabel Brand Image $\left(\mathrm{X}_{1}\right)$ dan Variabel Atribut Produk $\left(\mathrm{X}_{2}\right)$ berpengaruh positif dan signifikan terhadap Variabel Minat Beli (Y). 98,4\% Variabel Minat Beli (Y) Handphone merek Oppo akan pengaruhi oleh Variabel Brand Image $\left(\mathrm{X}_{1}\right)$ dan Variabel Atribut Produk $\left(\mathrm{X}_{2}\right)$ sedangkan sisanya sebesar 1,6\% akan dipengaruhi oleh faktor lain di luar persamaan model regresi. Sudah selayaknya pebisnis Handphone tetap memperhatikan Brand Image dan Atribut Produk untuk meningkatkan minat beli konsumen.

\section{DAFTAR PUSTAKA}

Aaker, David A. 2011. Manajemen Ekuitas Merek: Memanfaatkan Nilai Dari Suatu Merek. (terjemahan: Aris Ananda). Jakarta: Spektrum Mitra Utama

Anoraga. Pandji. 2000. Manajemen Bisnis. Jakarta: PT. Rineka Cipta

Arikunto, Suharsimi. (2013). Prosedur Penelitian Suatu Pendekatan Praktik. Jakarta: PT Rineka Cipta.

Bungin. 2008. Metodologi Penelitian Kuantitatf. Jakarta: Prenada Media Group

Durianto. dkk. 2003. Invasi Pasar dengan Iklan yang Efektif: Strategi. Program. dan Teknik Pengukuran. Jakarta: Gramedia Pustaka Utama

Ferdinand, Augusty. 2002. Pengembangan Minat Beli Merek Ekstensi.Semarang: Badan Penerbit Universitas Diponegoro.

Kotler. Philip. 2000. Prinsip-Prinsip Pemasaran Manajemen. Jakarta: Prenhalindo .2007. Manajemen Pemasaran. Jakarta : PT.Indeks. 2008. Manajemen Pemasaran. Edisi Milenium. Jakarta: PT. Prehalindo.

Kotler, Philip, dan Gary Armstrong 2012. Prinsipprinsip Pemasaran. Edisi 13. Jilid 1. : Jakarta: Erlangga

Simamora, Bilson. 2001. Remarketing For Business Recovery. Cetakan Pertama. Jakarta : PT. Gramedia Pustaka Utama.

Stanton, William J. 2012. Prinsip pemasaran. alih bahasa: Yohanes Lamarto. Jakarta: Penerbit Erlangga

Sugiyono. 2007. Penelitian Kuantitatif, Kualitatif, dan $R \& D$, Bandung: Alfabeta

Sumarwan. Ujang. (2003). Perilaku Konsumen. Jakarta: Ghalia Indonesia

Swastha, Basu. 2000. Pengantar Bisnis Modern. Pengantar Ekonomi Perusahaan Modern. Jakarta : Liberty.

Thamrin, Abdullah. 2003. Manajemen Pemasaran. Jakarta: PT. Rajawali Pers.

Tjiptono, Fandy. 2008. Strategi Pemasaran. Edisi 3, Yogyakarta: Andi Offset

Yamit, Zulian. 2001. Manajemen Kualitas Produk dan Jasa. Yogyakarta: Ekonosia 